\title{
Characterization of venturi injector using dimensional analysis
}

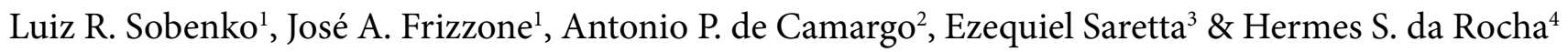 \\ ${ }^{1}$ Universidade de São Paulo/Escola Superior de Agricultura "Luiz de Queiroz"/Departamento de Engenharia de Biossistemas, Piracicaba, SP, Brasil. \\ E-mail: luizsobenko@usp.br (Corresponding author) - ORCID: 0000-0002-4958-9149; frizzone@usp.br - ORCID: 0000-0002-4251-1496 \\ ${ }^{2}$ Universidade Estadual de Campinas/Faculdade de Engenharia Agrícola, Campinas, SP, Brasil. E-mail: apcpires@unicamp.br - ORCID: 0000-0001- \\ 5164-2634 \\ ${ }^{3}$ Universidade Federal de Santa Maria/Departamento de Engenharia Agrícola, Cachoeira do Sul, RS, Brasil. E-mail: ezequiel.saretta@ufsm.br - ORCID: \\ 0000-0002-3893-3813 \\ ${ }^{4}$ Universidade Federal dos Vales do Jequitinhonha e Mucuri/Instituto de Ciências Agrárias, Unaí, MG, Brasil. E-mail: hermes.rocha@ufvjm.edu.br - \\ ORCID: 0000-0003-2389-8776
}

\begin{abstract}
Venturi injectors are commonly employed for fertigation purposes in agriculture, in which they draw fertilizer from a tank into the irrigation pipeline. The knowledge of the amount of liquid injected by this device is used to ensure an adequate fertigation operation and management. The objectives of this research were (1) to carry out functional tests of Venturi injectors following requirements stated by ISO 15873; and (2) to model the injection rate using dimensional analysis by the Buckingham Pi theorem. Four models of Venturi injectors were submitted to functional tests using clean water as motive and injected fluid. A general model for predicting injection flow rate was proposed and validated. In this model, the injection flow rate depends on the fluid properties, operating hydraulic conditions and geometrical characteristics of the Venturi injector. Another model for estimating motive flow rate as a function of inlet pressure and differential pressure was adjusted and validated for each size of Venturi injector. Finally, an example of an application was presented. The Venturi injector size was selected to fulfill the requirements of the application and the operating conditions were estimated using the proposed models.
\end{abstract}

Key words: Buckinghan Pi theorem, irrigation equipment, fertigation

\section{Caracterização de injetor venturi utilizando análise dimensional}

RESUMO: Injetores Venturi são comumente empregados para fins de fertirrigação na agricultura, extraindo fertilizante de um tanque para a linha de irrigação. O conhecimento da quantidade de líquido a ser injetado por este dispositivo é útil para assegurar operação e manejo adequados da fertirrigação. Os objetivos desta pesquisa foram: (1) conduzir testes funcionais de injetores Venturi seguindo as normas estabelecidas pela ISO 15873; e (2) modelar a vazão de injeção utilizando Análise Dimensional pelo teorema de Buckingham Pi. Quatro modelos de injetores Venturi foram submetidos a testes operacionais usando água limpa como fluido motriz e como fluido succionado. Um modelo geral para predição da vazão de injeção foi proposto e validado, sendo este dependente das propriedades do fluido, das condições hidráulicas operacionais e das características geométricas do injetor. Outro modelo para estimar a vazão motriz, em função da pressão de entrada e da pressão diferencial foi ajustado e validado para cada tamanho de Venturi. Finalmente, um exemplo de aplicação foi apresentado. O tamanho do injetor Venturi foi selecionado para atender aos requisitos da aplicação e as condições de operação foram estimadas utilizando os modelos propostos.

Palavras-chave: teorema de Buckinghan Pi, equipamento de irrigação, fertirrigação 


\section{INTRODUCTION}

Venturi tubes are commonly employed for fertigation purposes in agriculture (Frizzone et al., 2012). Venturi used as injectors rely on the Venturi pressure drop principle to draw chemicals from a stock tank into the irrigation pipeline (Hoffman et al., 2007).

The proper design, operation, and management of fertigation may enable uniform application of fertilizers and increase crop yields or their quality. Proper fertigation may also save fertilizers and reduce water usage by directly delivering water and nutrient near to crop roots, which boost economic and energy profitability to farmers (Sinha et al., 2017; Tian et al., 2017). However, inappropriate fertigation may reduce crop growth and yield, as well as may lead to environmental problems and contamination hazards related to soil, groundwater and surface water (Silva et al., 2013).

Several papers have studied the design, performance and modeling of Venturi injectors for agricultural purposes (Feitosa Filho et al., 1998, 1999; Lima Neto \& Porto, 2004). Techniques of computational fluid dynamics (CFD) simulations are also a useful tool to know the flow behavior inside a Venturi injector (Kuldeep \& Saharan, 2016; Manzano et al., 2016). However, in these papers, each model of evaluated Venturi injector had a corresponding regression model.

The amount of liquid fertilizer injected by a Venturi tube is influenced by its design, operational parameters, and water properties. A few prediction models for estimating the injection rate are found in the literature, but they are limited for use in gas applications (Liu et al., 2014; Xu et al., 2015; Gupta et al., 2016). Moreover, no general models were found in the literature to predict the injection rate of Venturi tubes used for agricultural purposes. ISO 15873 (ISO, 2002) specifies construction and operational requirements, as well as test methods for Venturi tubes employed as liquid injectors in irrigation systems. Functional tests described by that standard do not mention any models for estimation of injection rate.

The objectives of this research were (1) to carry out functional tests of Venturi tubes following requirements stated by ISO 15873 (ISO, 2002); (2) to model the injection rate of Venturi tubes for practical purposes using dimensional analysis by the Buckingham $\mathrm{Pi}$ theorem. In practice, the functional tests are required to determine operational characteristics of Venturi injectors, that are necessary to set variables and obtain a target injection flow. Results of those tests basically enable to relate motive flow, inlet pressure, differential pressure and injection flow. In addition, a general model is useful because a single equation enables to relate dimensions and operational characteristics of a range of Venturi sizes operating within a range of conditions.

\section{Material ANd Methods}

Four models of Venturi injectors were submitted to the functional tests stated by ISO 15873 (ISO 2002) at the Irrigation Testing Laboratory (LEMI) of the Escola Superior de Agricultura Luiz de Queiroz (ESALQ/USP), Piracicaba, São Paulo State, Brazil (22 $42^{\prime}$ S; $47^{\circ} 30^{\prime}$ W; and altitude of $546 \mathrm{~m}$ ). Table 1 shows the geometric characteristics of the evaluated devices. Models 1, 2 and 3 were manufactured by Amanco
Table 1. Geometrical characteristics of evaluated Venturi injectors: nominal outlet diameter (DN), internal inlet diameter $\left(D_{\text {in }}\right)$, throat diameter $\left(D_{t}\right)$, and injection pipe diameter $\left(D_{\text {inj }}\right)$

\begin{tabular}{clcrrr}
\hline $\begin{array}{c}\text { Venturi } \\
\text { model }\end{array}$ & Manufacturer & DN model & $\mathbf{D}_{\text {in }}$ & $\mathbf{D}_{\mathbf{1}}$ & $\mathbf{D}_{\text {inj }}$ \\
\cline { 4 - 6 } & (inch) & & $(\mathbf{m m})$ \\
\hline 1 & Amanco Ltda. & $3 / 4$ & 12.60 & 4.24 & 6.20 \\
\hline 2 & Amanco Ltda. & 1 & 19.45 & 7.56 & 12.80 \\
\hline 3 & Amanco Ltda. & $11 / 2$ & 33.45 & 10.40 & 12.80 \\
\hline 4 & Mondo Irrigação & $11 / 2$ & 28.60 & 10.20 & 12.80 \\
\hline
\end{tabular}

Ltda. while Mondo Irrigação manufactured Venturi Model 4, being both Brazilian companies. The four models represent the commercial sizes of Venturi tubes usually employed for fertigation purposes in Brazil and all of them had a check valve integrated at their injection inlet. The check valve is designed to avoid reverse flow through the injection pipe and is a simple device consisting of a spring, plastic sphere, and a rubber sealing ring. As demonstrated by Santos et al. (2012), when check valves were integrated to Venturi injectors, their influence on hydraulic operational characteristics was not relevant for fertigation purposes. Figure 1 illustrates the geometric characteristics of an ordinary Venturi injector.

Tests were undertaken in a testing bench (Figure 2) that consisted of a pump and an automated system for pressure

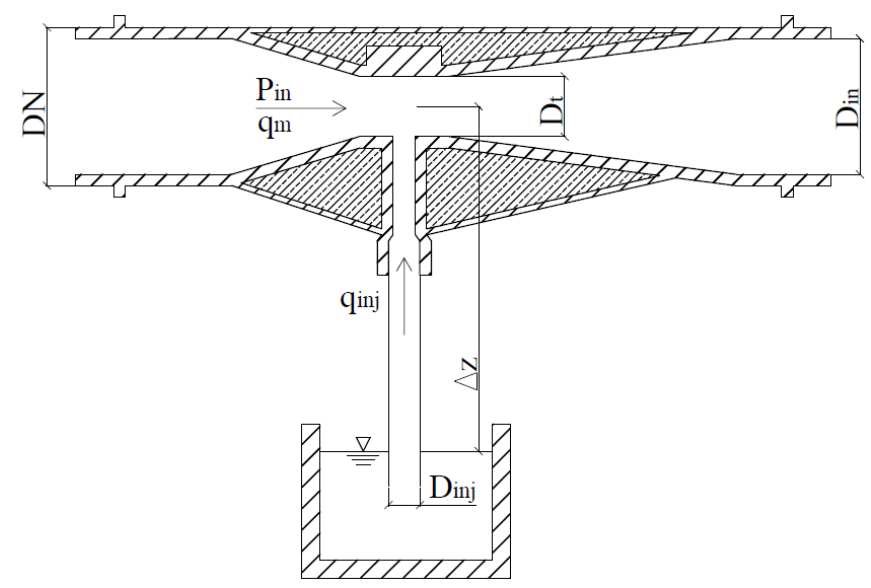

$\mathrm{DN}$ - Nominal outlet diameter (inches), $\mathrm{P}_{\text {in }}$ - Inlet pressure $(\mathrm{Pa}), \mathrm{q}_{\mathrm{m}}$ - Motive flow rate $\left(\mathrm{m}^{3} \mathrm{~s}^{-1}\right), \mathrm{D}_{\mathrm{t}}$ - Throat diameter $(\mathrm{m}), \mathrm{D}_{\mathrm{in}}$ - Internal inlet diameter $(\mathrm{m}), \mathrm{q}_{\mathrm{inj}}$ - Injection flow rate $\left(\mathrm{m}^{3} \mathrm{~s}^{-1}\right), \Delta \mathrm{z}$ - Distance between the surface of the suctioned water and the Venturi $(\mathrm{m}), \mathrm{D}_{\text {inj }}$ - Injection pipe diameter $(\mathrm{m})$

Figure 1. Main geometric characteristics of a Venturi injector

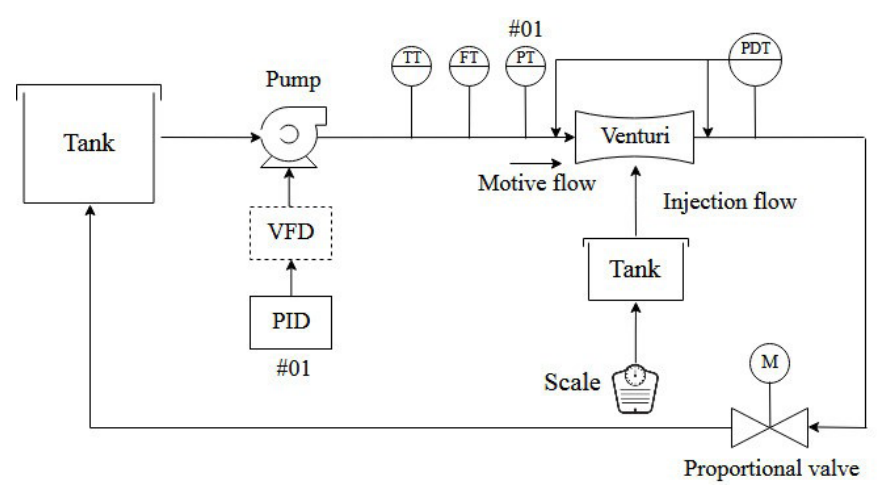

VFD - Variable frequency drive, PID - Proportional-integral-derivative controller, M Indicates that the proportional valve is controlled by an electric motor

Figure 2. Instrumentation diagram of the testing bench used for functional tests of Venturi injectors: (TT) Temperature transmitter; (FT) flow transmitter; (PT) pressure transmitter; (PDT) differential pressure transmitter 
control and equipped with a variable frequency drive (VFD) and proportional-integral-derivative (PID) controller. The PID controller used a pressure transmitter, installed at the inlet of the Venturi tube, to calculate the error between the pressure set point and the measured pressure, and then applied an output signal to the variable frequency drive.

Each injector was mounted in-line, with the full main flow introduced as motive water at the injector inlet ISO 15873 (ISO, 2002). Clean water was used as motive and injected fluid to comply with ISO 15873 (ISO, 2002). Although experiments evaluating various fluids do not belong to the scope of this research, literature indicates that viscosity and density variation between motive fluid and injected fluid affects operational characteristics of Venturi injectors (Yuan et al., 2000; Kumar et al., 2012).

ISO 15873 (ISO, 2002) also states that the relative elevations of the suction port and the surface of the suction water must remain constant during the test. During all experiments, the vertical distance between the surface of the suctioned water and the Venturi was set to $1 \mathrm{~m}$ (see $\Delta \mathrm{z}$ in Figure 1). Variations of such vertical distances are beyond the scope of this research. Each device was evaluated at five inlet pressures ranging from 100 to $300 \mathrm{kPa}$ in intervals of $50 \mathrm{kPa}$. The range of inlet pressures was defined based on practical values commonly used in microirrigation and low-pressure sprinkler systems. For each inlet pressure, the motive flow was set in order to provide differential pressures of $20,40,60,80$ and $100 \%$ in relation to the inlet pressure ISO 15873 (ISO, 2002).

A pressure transmitter (measurement ranging from 0 to $500 \mathrm{kPa}$, resolution of $0.1 \mathrm{kPa}$, maximum error of $0.1 \%$ of full scale) was installed at the inlet of the Venturi to monitor the inlet pressure and to provide the feedback signal required by the PID controller. A differential pressure transmitter (measurement ranging from 0 to $500 \mathrm{kPa}$, resolution of $0.01 \mathrm{kPa}$, and maximum error of $0.1 \%$ of full scale) monitored the differential pressure between the inlet and outlet of the Venturi. Two models of electromagnetic flowmeters were used for measuring motive flow rates. The motive flow of Venturi Models 1 and 2 was measured using a flowmeter of measurement ranging from 0 to $4 \mathrm{~m}^{3} \mathrm{~h}^{-1}$, while for the other models of Venturi a flowmeter of measurement ranging from 0 to $10 \mathrm{~m}^{3} \mathrm{~h}^{-1}$ was employed. Both flowmeters have a resolution of $0.001 \mathrm{~m}^{3} \mathrm{~h}^{-1}$ and expanded uncertainty of $0.5 \%$ in relation to their full range.

The injection rate was measured by the gravimetric method using a precision scale (measurement ranging from 0 to $100 \mathrm{~kg}$, resolution of $0.01 \mathrm{~kg}$ ) and a stopwatch. Water temperature was monitored using a temperature transmitter of measurement ranging from 0 to $50{ }^{\circ} \mathrm{C}$, resolution of $0.1^{\circ} \mathrm{C}$, and maximum error of $0.1 \%$ of full scale. A proportional valve was used for adjusting the testing flow rate (Figure 2).

Models based on dimensional analysis were developed to estimate pressure losses in drip irrigation laterals (Perboni et al., 2015), pressure losses in filters (Duran-Ros et al., 2010; Wu et al., 2014), minor losses in microirrigation connectors (Zitterell et al., 2013; Vilaça et al., 2017) and to study hydraulics of microtubes (Vekariya et al., 2010).

In this research, the dimensional analysis was based on the Buckingham Pi theorem (Buckingham, 1914) and the method of repeating variables, following practical procedures defined by Fox et al. (2011).

The Venturi injection rate is mainly influenced by its geometric characteristics, motive flow rate, differential and inlet pressures, and water properties. Based on such empirical interpretation of this physical process, a mathematical relationship can be defined (Eq. 1):

$$
\mathrm{q}_{\text {inj }}=\mathrm{f}\left(\Delta \mathrm{P}, \mathrm{P}_{\mathrm{in}}, \mathrm{q}_{\mathrm{m}}, \rho, \mu, \mathrm{D}_{\text {in }}, \mathrm{D}_{\text {inj }}, \mathrm{D}_{\mathrm{t}}\right)
$$

where:

$\mathrm{q}_{\text {inj }} \quad$ - injection flow rate, $\mathrm{m}^{3} \mathrm{~s}^{-1}$;

$\Delta \mathrm{P} \quad$ - differential pressure, $\mathrm{Pa}$;

$\mathrm{P}_{\text {in }} \quad$ - inlet pressure, $\mathrm{Pa}$;

$\mathrm{q}_{\mathrm{m}} \quad$ - motive flow rate, $\mathrm{m}^{3} \mathrm{~s}^{-1}$;

$\rho \quad$ - water density, $\mathrm{kg} \mathrm{m}^{-3}$;

$\mu \quad$ - water dynamic viscosity, Pa s;

$\mathrm{D}_{\text {in }}$ - internal inlet diameter, $\mathrm{m}$;

$\mathrm{D}_{\text {inj }}$ - injection pipe diameter, $\mathrm{m}$; and,

$\mathrm{D}_{\mathrm{t}} \quad$ - throat diameter, $\mathrm{m}$.

Lemons (2017) pointed out that the number of variables necessary to represent a process should be minimized. Including unnecessary predictors in the model complicates the description of the process and may result in poor predictions, while omitting important effects reduce its predictive power (Chatterjee \& Simonoff, 2013). A model should be as simple as possible while still accounting for the important relationships in the data (Vilaça et al., 2017). In addition, to facilitate grouping of Pi-terms ( $\Pi)$, injection and motive rates were expressed as flow velocities. Finally, the mathematical relationship assumed to represent the physical process is shown in Eq. 2.

$$
v_{\text {inj }}=f\left(\Delta P, P_{\text {in }}, v_{m}, \rho, \mu, D_{\text {in }}, D_{\text {inj }}, D_{t}\right)
$$

where:

$\mathrm{v}_{\text {inj }}$ - injection flow velocity, $\mathrm{m} \mathrm{s}^{-1}$; and,

$\mathrm{v}_{\mathrm{m}}$ - motive flow velocity at inlet section, $\mathrm{m} \mathrm{s}^{-1}$.

The physical properties $\rho$ and $\mu$ varies as a function of temperature and fluid. In this research those properties were assumed to be constant: $\rho=1000 \mathrm{~kg} \mathrm{~m}^{-3}$ and $\mu=1.01 \times 10^{-3} \mathrm{~Pa}$. The quantification of the effects of solute concentration and liquid viscosity and temperature in injection rate of Venturi injectors are described in Yuan et al. (2000) and Kumar et al. (2012).

The difference between the number of variables that describe a process $(\mathrm{k})$ and the number of reference dimensions (r) required to define units to the list of variables results in the number of dimensionless groups (i.e., the Pi-terms). In Eq. 2 it can be observed nine variables $(\mathrm{k}=9)$ associated with three reference dimensions ( $\mathrm{M}, \mathrm{L}, \mathrm{T} ; \mathrm{r}=3)$. So, the number of $\mathrm{Pi}$ terms is equal to six (Eq. 3).

$$
\Pi_{1}=\phi\left(\Pi_{2}, \Pi_{3}, \Pi_{4}, \Pi_{5}, \Pi_{6}\right)
$$

where:

$\Pi_{\mathrm{n}} \quad$ - Pi-term, dimensionless; and, 
$\phi \quad$ - functional relationship between the variables.

The method of repeating variables was used to form the dimensionless groups. This method requires the selection of the so-called "repeating variables" following a specific set of rules mentioned by Fox et al. (2011). From Eq. 2, the injection flow velocity $\left(\mathrm{v}_{\text {inj }}\right)$ was chosen as the dependent variable and the repeating variables were $v_{m}, D_{\text {in }}$ and $\rho$. Thereafter, the repeating variables were systematically combined with the remainder variables in order to define the Pi-terms (Eq. 4).

$$
\frac{\mathrm{v}_{\text {inj }}}{\mathrm{v}_{\mathrm{m}}}=\phi\left(\frac{\Delta \mathrm{P}}{\rho \mathrm{v}_{\mathrm{m}}^{2}}, \frac{\mathrm{P}_{\mathrm{in}}}{\rho \mathrm{v}_{\mathrm{m}}^{2}}, \frac{\rho \mathrm{v}_{\mathrm{m}} \mathrm{D}_{\text {in }}}{\mu}, \frac{\mathrm{D}_{\text {inj }}}{\mathrm{D}_{\text {in }}}, \frac{\mathrm{D}_{\mathrm{t}}}{\mathrm{D}_{\text {in }}}\right)
$$

The Eq. 4 represents a fundamental relationship that describes the physical process of injection flow velocity in Venturi injectors. Each dimensionless term shown in Eq. 4 corresponds to a Pi-term indicated by Eq. 3 .

A multivariate power-law model (Eq. 5) was fitted to the data using the least square method. Such a model has been employed successfully for modeling processes related to fluid flow in hydraulics and irrigation applications (Vekariya et al., 2010; Zitterel et al., 2013; Perboni et al., 2015; Vilaça et al., 2017).

$$
\Pi_{1}=\beta_{1} \Pi_{2}^{\beta_{2}} \Pi_{3}^{\beta_{3}} \ldots \Pi_{\mathrm{n}}^{\beta_{\mathrm{n}}}
$$

where:

$\beta_{\mathrm{n}} \quad$ - empirical coefficient, dimensionless.

The dataset obtained experimentally was randomly divided into two subsets: the calibrating and the testing dataset. The calibrating dataset accounted for $70 \%$ of the whole experimental data and was used to fit the models. The testing dataset consisted of the remaining $30 \%$ data and was used to assess the accuracy/performance of the model.

Additionally, for each model of Venturi, the motive flow was estimated as a function of $\Delta \mathrm{P}$ and $\mathrm{P}_{\text {in }}$ (Eq. 6). The model was fitted by the software Sigmaplot and its coefficients were adjusted using the least square method.

$$
\mathrm{q}_{\mathrm{m}}=\alpha_{1}+\alpha_{2} \mathrm{P}_{\mathrm{in}}+\alpha_{3} \Delta \mathrm{P}+\alpha_{4} \mathrm{P}_{\text {in }}^{2}+\alpha_{5} \Delta \mathrm{P}^{2}
$$

where:

$a_{n} \quad$ - empirical coefficient, dimensionless.

Models were assessed by the root mean square error (RMSE) and by graphical error analysis. The RMSE is a common index to measure the accuracy of models that quantify differences between observed and estimated values (Duran-Ros et al., 2010; Provenzano et al., 2016). The graphical error analysis is also useful to quantify prediction errors while evaluating the accuracy of models because it provides prediction errors associated with their frequency of occurrence (Vilaça et al., 2017).

\section{Results AND Discussion}

For each model of Venturi, 25 testing conditions were evaluated. Therefore, the gathered experimental data accounts for 100 records obtained from functional tests of four models of Venturi injectors. Figure 3 shows the experimental results.

The injection flow rate was more sensitive to changes in the differential pressure $(\Delta \mathrm{P})$ when the Venturi was operated under low values of inlet pressure $\left(\mathrm{P}_{\text {in }}\right.$ - i.e., 100 and $\left.150 \mathrm{kPa}\right)$. Generally, for $\mathrm{P}_{\text {in }}$ higher than $200 \mathrm{kPa}$ and for $\Delta \mathrm{P} / \mathrm{P}_{\text {in }}$ higher than $60 \%, \mathrm{q}_{\text {inj }}$ was relatively constant. According to Lamm et al. (2006), the injection rate is relatively insensitive to irrigation pipeline pressure changes when Venturi injectors are operated under inlet pressures higher than about $200 \mathrm{kPa}$. Moreover, the authors recommend maintaining high values of $\Delta \mathrm{P} / \mathrm{P}_{\text {in }}$ when a constant chemical injection is required.

For inlet pressures ranging from 100 to $300 \mathrm{kPa}, \mathrm{q}_{\mathrm{inj}}$ varied from 0 to $0.095 \mathrm{~m}^{3} \mathrm{~h}^{-1}, 0$ to $0.483 \mathrm{~m}^{3} \mathrm{~h}^{-1}, 0$ to $0.652 \mathrm{~m}^{3} \mathrm{~h}^{-1}$ and 0.006 to $0.422 \mathrm{~m}^{3} \mathrm{~h}^{-1}$ for Venturi Models 1, 2, 3 and 4, respectively (Figure 3). As shown in Table 1, all geometrical characteristics increase for Venturi injector Models 1 to 3. Model 3 presented the highest values of $\mathrm{q}_{\text {inj }}$ (Figures $3 \mathrm{E}$ and F), which is an expected result since that model has the largest dimensions. The injection rate of Venturi Model 4 (Figures $3 \mathrm{G}$ and $\mathrm{H}$ ) represents $64.7 \pm 5.2 \%$ of Model 3. Models 3 and 4 have the same nominal diameter (DN), but different internal dimensions. The inlet diameter $\left(\mathrm{D}_{\text {in }}\right)$ and the throat diameter $\left(\mathrm{D}_{\mathrm{t}}\right)$ of Model 4 are $14.5 \%$ and $1.9 \%$ smaller than Model 3, respectively. Manzano et al. (2018) pointed out that some manufacturers give insufficient information in their catalogs, mainly in relation to the dimensions and diameters. The parameter normally used by manufacturers to differentiate Venturi tubes is a nominal diameter, without specifying the respective internal diameters, the internal throat diameter or the injection diameter $\left(\mathrm{D}_{\text {inj }}\right)$.

Comparing the same manufacturer Venturi tubes, Model 1 (Figures $3 \mathrm{~A}$ and $\mathrm{B}$ ) represents on average $19.6 \pm 1.3 \%$ and $14.57 \pm 1.0 \%$ of the injection rate capacity of Models 2 and 3 , respectively. Venturi tube Model 2 (Figures 3C and D) represents $74.1 \pm 3.3 \%$ of the Model 3 injection rate capacity as well. In this case, the motive and injection flow rates increased with the internal and injection diameters. Manzano et al. (2015), while evaluating performance and alternative setup of four Venturi tubes, reported a similar trend.

The empirical coefficients of Eq. 5 were fitted using the calibration dataset. A full model was evaluated and shown in Eq. 7.

$$
\frac{\mathrm{v}_{\mathrm{inj}}}{\mathrm{v}_{\mathrm{m}}}=0.0046\left(\frac{\Delta \mathrm{P}}{\rho \mathrm{v}_{\mathrm{m}}^{2}}\right)^{0.2841}\left(\frac{\mathrm{P}_{\mathrm{in}}}{\rho \mathrm{v}_{\mathrm{m}}^{2}}\right)^{-1.4899}\left(\frac{\rho \mathrm{v}_{\mathrm{m}} \mathrm{D}_{\mathrm{in}}}{\mu}\right)^{-0.0591}\left(\frac{\mathrm{D}_{\mathrm{inj}}}{\mathrm{D}_{\mathrm{in}}}\right)^{2.7966}\left(\frac{\mathrm{D}_{\mathrm{t}}}{\mathrm{D}_{\mathrm{in}}}\right)^{-10.9511}
$$

Eq. 7 is valid for: $12.5258 \leq \Delta \mathrm{P} / \rho v^{2}{ }_{m} \leq 59.3003 ; 22.1238 \leq$ $\mathrm{P}_{\text {in }} / \rho v_{\mathrm{m}}^{2} \leq 64.3450 ; 15563 \leq \rho \mathrm{v}_{\mathrm{m}} \mathrm{D}_{\text {in }} / \mu \leq 87544 ; 0.3827 \leq \mathrm{D}_{\mathrm{inj}} /$ $\mathrm{D}_{\text {in }} \leq 0.6581 ; 0.3109 \leq \mathrm{D}_{\mathrm{t}} / \mathrm{D}_{\text {in }} \leq 0.3889$. The units of the terms in the equations are: $\Delta \mathrm{P}$ and $\mathrm{P}_{\text {in }}=\mathrm{Pa} ; \mathrm{q}_{\text {inj }}$ and $\mathrm{q}_{\mathrm{m}}=\mathrm{m}^{3} \mathrm{~s}^{-1} ; \mathrm{D}_{\text {in }}$, $\mathrm{D}_{\text {inj }}$, and $\mathrm{D}_{\mathrm{t}}=\mathrm{m} ; \rho=\mathrm{kg} \mathrm{m}^{-3} ; \mu=\mathrm{Pa} \mathrm{s}$.

Expressing the flow velocities as flow rates and rearranging the terms of Eq. 7, the proposed model to estimate the Venturi injection rate is presented in Eq. 8.

$$
\mathrm{q}_{\text {inj }}=0.0082 \rho^{1.1468} \mu^{0.0591} \frac{\mathrm{q}_{\mathrm{m}}^{3.3527} \Delta \mathrm{P}^{0.2841}}{\mathrm{P}_{\mathrm{in}}^{1.4899}} \frac{\mathrm{D}_{\mathrm{in}}^{1.3901} \mathrm{D}_{\mathrm{inj}}^{4.7966}}{\mathrm{D}_{\mathrm{t}}^{10.9511}}
$$


A.

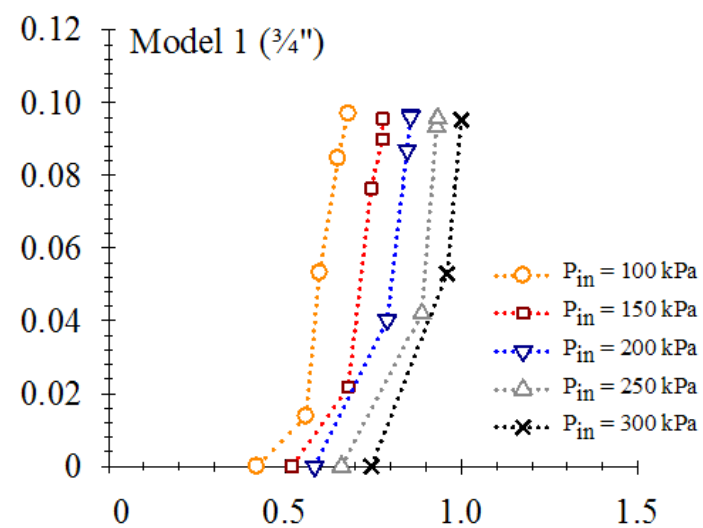

C.
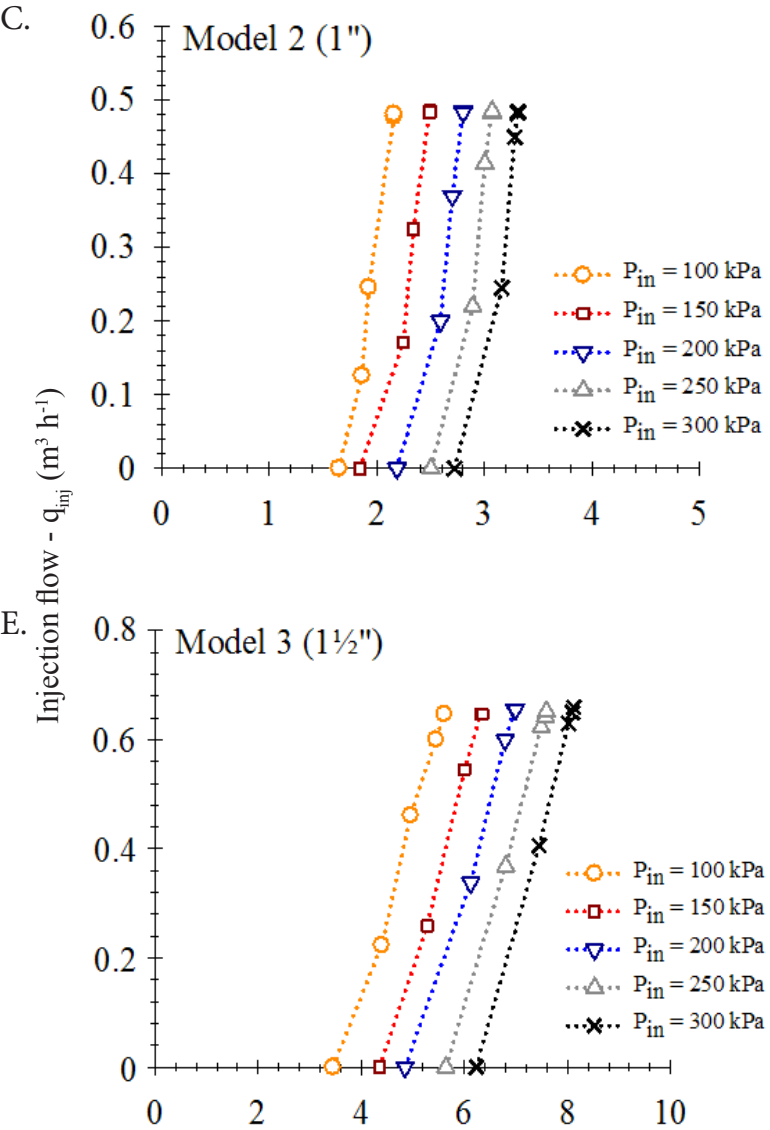

G.

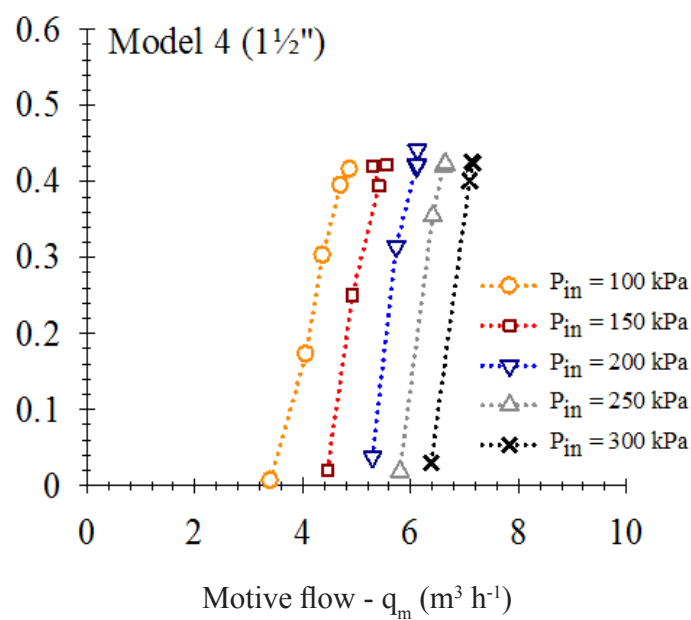

B. $\quad 0.12$ F Model $1(3 / 4 ")$

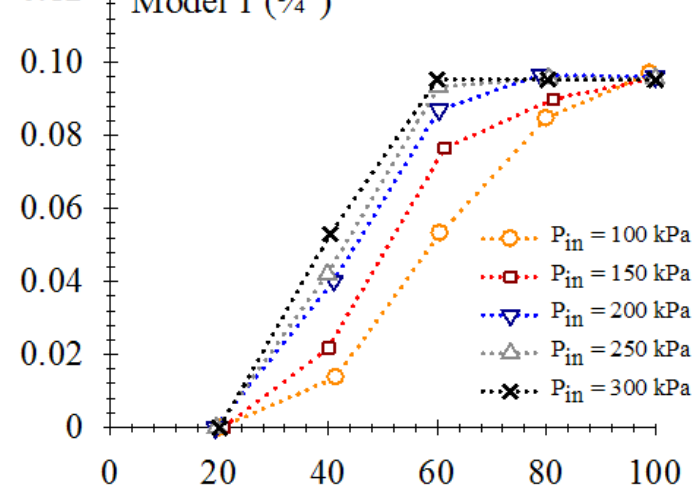

D. $\quad 0.6$ 毛 Model 2 (1")

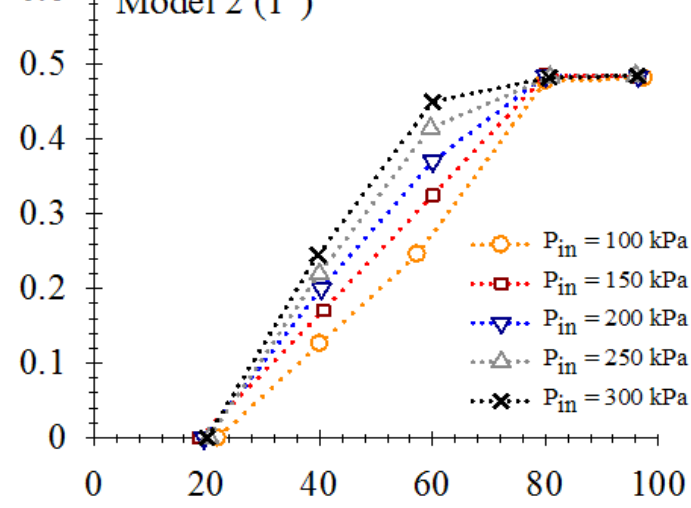

F. $\quad 0.8$ T Model $3\left(1 \frac{1 / 2 ")}{}\right.$

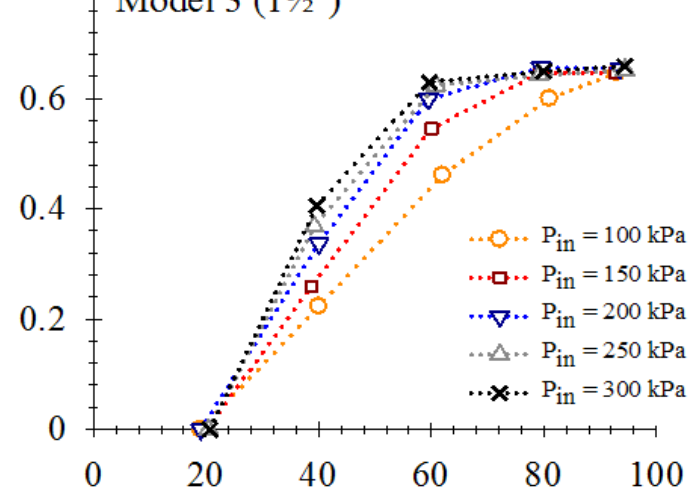

H.

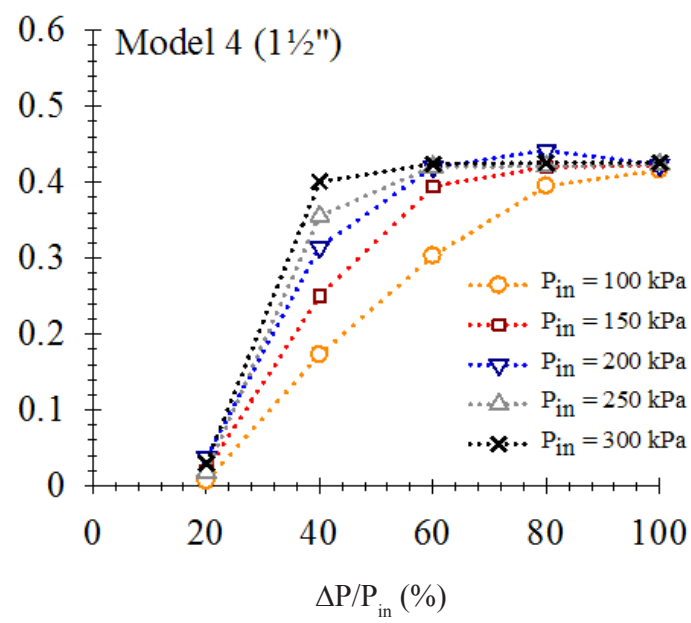

$\Delta \mathrm{P}$ - Differential pressure (Pa), Pin - Inlet pressure (Pa)

Figure 3. Data obtained from the functional tests of four models of Venturi injectors evaluated under 5 conditions of inlet pressure: $(A, C, E$ and $G)$ injection flow as a function of motive flow; $(B, D, F$ and $H)$ injection flow as a function of $\Delta P / P_{\text {in }}$ 
Figure 4A shows the fitting and validation scattering data, and RMSE values as well, of the predicted $\mathrm{q}_{\text {inj }}$ by the model. The RMSE values were very similar which indicate the accuracy of the model. For this model, relative errors lower than $10 \%$ were observed in $79.5 \%$ of the predictions, while $95 \%$ of predictions presented relative errors of up to $29.1 \%$ (Figure 4C).

Due to the high dependence among $\mathrm{q}_{\text {inj }}, \mathrm{q}_{\mathrm{m}}, \Delta \mathrm{P}$, and $\mathrm{P}_{\text {in' }}$, and the observed high sensitivity of $\mathrm{q}_{\mathrm{inj}}$ to variations in $\mathrm{q}_{\mathrm{m}}$ during the data analysis (Figure 3), it was not possible to fit a general model to predict $\mathrm{q}_{\mathrm{m}}$. According to Frizzone et al. (2012) and Manzano et al. (2018), changes in flow rate or operating pressure may affect the other hydraulic parameters. In this way, a multivariate model (Eq. 6) was fitted for each evaluated Venturi injector as a function of $\Delta \mathrm{P}$ and $\mathrm{P}_{\text {in }}$, and their coefficients are shown in Table 2.
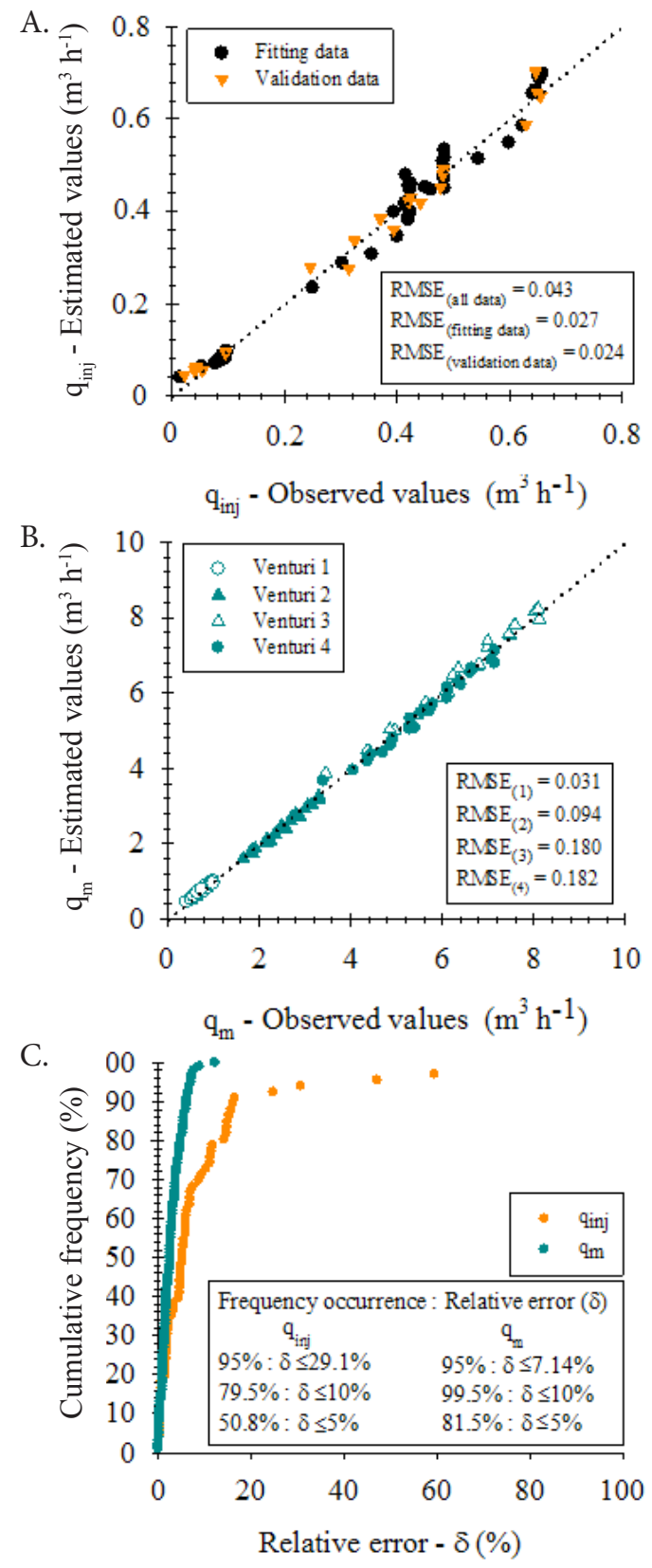

Figure 4. Comparison between the proposed model on predicting the injection $\left(\mathrm{q}_{\mathrm{inj}}\right)$ and motive $\left(\mathrm{q}_{\mathrm{m}}\right)$ flow rates: $(A)$ observed versus estimated values of $\mathrm{q}_{\mathrm{inj}}$; (B) observed versus estimated values of $\mathrm{q}_{\mathrm{m}}$; and $(\mathrm{C})$ graphical error analysis presenting relative errors $(\delta)$ versus frequency prediction errors
Table 2. Coefficients adjusted for each model of Venturi to estimate $\mathrm{q}_{\mathrm{m}}$ as a function of $\Delta \mathrm{P}$ and $\mathrm{P}_{\mathrm{in}}$ (Eq. 6)

\begin{tabular}{cccccc}
\hline Venturi & \multicolumn{5}{c}{ Coelficients } \\
\cline { 2 - 6 } model & $\boldsymbol{\alpha}_{1}$ & $\boldsymbol{\alpha}_{2}$ & $\boldsymbol{\alpha}_{3}$ & $\boldsymbol{\alpha}_{4}$ & $\boldsymbol{\alpha}_{5}$ \\
\hline 1 & $8.9 \times 10^{-5}$ & $1.27 \times 10^{-10}$ & $1.15 \times 10^{-9}$ & $3.97 \times 10^{-16}$ & $-2.72 \times 10^{-15}$ \\
2 & $3.0 \times 10^{-4}$ & $8.61 \times 10^{-10}$ & $2.58 \times 10^{-9}$ & $8.40 \times 10^{-16}$ & $-5.98 \times 10^{-15}$ \\
3 & $8.0 \times 10^{-4}$ & $8.38 \times 10^{-10}$ & $9.24 \times 10^{-9}$ & $3.10 \times 10^{-15}$ & $-2.17 \times 10^{-14}$ \\
4 & $6.0 \times 10^{-4}$ & $3.50 \times 10^{-9}$ & $4.68 \times 10^{-9}$ & $-1.27 \times 10^{-15}$ & $-1.17 \times 10^{-14}$ \\
\hline
\end{tabular}

The RMSE values of the predicted $q_{m}$ for each model are presented in Figure $4 \mathrm{~B}$ and the frequency of occurrence associated with values of relative errors (Figure 4C) indicates the similar accuracy of both models.

Manzano et al. (2015) evaluated four different Venturi models installed in-line. By regressions, the authors obtained two models for predicting the injection rate. However, one of the models only varies by the differential pressure, while the other varies with both the differential pressure and inlet pressure. When these models were obtained, the authors did not take into account the variation of dimensions of the Venturi tubes, the geometric characteristics of the injection pipes, and water properties.

In practice, Venturi injectors are commonly installed in a by-pass setup ISO 15873 (ISO, 2002), which renders controlling the motive flow rate more difficult due to the withdrawing of water from the main irrigation pipeline (Manzano et al., 2018). However, a single manometer would make it possible to control the differential pressure by opening or closing a valve installed across the irrigation pipeline, which generates negative pressure inside the injector and, consequently, the suction of the solution.

To demonstrate the use of the proposed equations, it is necessary to choose the size and to estimate the differential pressure of a Venturi injector that is able to operate in the following application. A microirrigation subunit with an area of $5 \mathrm{ha}$; the pressure at the inlet of the subunit is $300 \mathrm{kPa}$; irrigation duration of $5 \mathrm{~h}$; and a need to apply $30 \mathrm{~kg} \mathrm{ha}^{-1}$ of nitrogen from a liquid fertilizer with a nutrient concentration of $0.42 \mathrm{~kg} \mathrm{~L}^{-1}$. The fertigation duration normally corresponds to $80 \%$ of the irrigation duration. It is a practical recommendation commonly used for the correct application of nutrients to the crop (Frizzone et al., 2012).

As calculation steps, the amount of liquid fertilizer required is $357.14 \mathrm{~L}$, and the fertigation duration is $4 \mathrm{~h}$; hence the required injection flow is $89.3 \mathrm{~L} \mathrm{~h}^{-1}$. From this value, the size of the Venturi injector can be defined. Venturi Model 1 fulfills the application since its injection flow ranges from 0 to $0.095 \mathrm{~m}^{3} \mathrm{~h}^{-1}$ (Figure 3).

The geometric characteristics of the Venturi Model 1 are known (Table 1). It is assumed that the water dynamic viscosity is $1.003 \times 10^{-3} \mathrm{~Pa} \mathrm{~s}$ and its density is $1000 \mathrm{~kg} \mathrm{~m}^{-3}$. Therefore, the unknown variables in Eq. 8 are $\Delta$ P and $\mathrm{q}_{\mathrm{m}}$. From Eq. 6 adjusted for Venturi Model 1 (coefficients given in Table 2), the unknown variables also are $\Delta \mathrm{P}$ and $\mathrm{q}_{\mathrm{m}}$. The differential pressure required to obtain the injection flow rate of $0.0893 \mathrm{~m}^{3} \mathrm{~h}^{-1}$ is calculated by iterations. Finally, the differential pressure should be adjusted to $212.8 \mathrm{kPa}$ in order to obtain the target injection flow rate of $0.0893 \mathrm{~m}^{3} \mathrm{~h}^{-1}$. Under this operating condition, the motive flow is $1.024 \mathrm{~m}^{3} \mathrm{~h}^{-1}$, the ratio $\Delta \mathrm{P} / \mathrm{P}_{\text {in }}$ is $70.9 \%$, and the 
pressure at the outlet of the Venturi is $87.2 \mathrm{kPa}$. This operating condition will enable a stable and accurate application of the desired amount of nitrogen. Also, the pressure of $87.2 \mathrm{kPa}$ is enough to properly operate most emitters employed in microirrigation systems.

\section{Conclusions}

1. For all evaluated models, the injection flow rate was positive for $\Delta \mathrm{P} / \mathrm{P}_{\text {in }}$ ratios higher than $20 \%$, regardless of the inlet pressure.

2. The injection flow rate was more sensitive to changes in the motive flow rate and the differential pressure when the Venturi injector was operated under low values of inlet pressure (i.e., 100 and $150 \mathrm{kPa}$ ).

3. Generally, under inlet pressures higher than $200 \mathrm{kPa}$ and for $\Delta \mathrm{P} / \mathrm{P}_{\text {in }}$ ratios higher than $60 \%$, the injection flow rate was relatively constant.

4. A general model for predicting injection flow rate was proposed and validated, which depends on the fluid properties, hydraulic operating conditions and geometrical characteristics of the Venturi injector. Another model for estimating motive flow rate as a function of inlet pressure and differential pressure was adjusted and validated for each size of the Venturi injector.

\section{Literature Cited}

Buckingham, E. On physically similar systems: Illustrations of the use of dimensional equations. Physical Review, v.4, p.345-376, 1914. https://doi.org/10.1103/PhysRev.4.345

Chatterjee, S.; Simonoff, J. Handbook of regression analysis. Hoboken: John Wiley \& Sons, 2013. 236p. https://doi. org/10.1002/9781118532843

Duran-Ros, M.; Arbat, G.; Barragán, J.; Ramírez de Cartagena, F.; Puig-Bargués, J. Assessment of head loss equations developed with dimensional analysis for micro irrigation filters using effluents. Biosystems Engineering, v.106, p.521-526, 2010. https://doi. org/10.1016/j.biosystemseng.2010.06.001

Feitosa Filho, J. C.; Botrel, T. A.; Pinto, J. M. Desempenho de injetores tipo venturi em condições de descarga livre e pressurizada. Engenharia Agrícola, v.17, p.20-35, 1998.

Feitosa Filho, J. C.; Pinto, J. M.; Arruda, N. T. de. Dimensionamento, construção e características hidráulicas de um injetor tipo venturi para uso na quimigação. Irriga, v.4, p.43-53, 1999. https://doi. org/10.15809/irriga.1999v4n2p43-53

Fox, R. W.; McDonald, A. T.; Pritchard, P. J. Introduction to fluid mechanics. 8.ed. Hoboken: John Wiley \& Sons, 2011. 896p.

Frizzone, J. A.; Freitas, P. S. L. de; Rezende, R.; Faria, M. A. de. Microirrigação: Gotejamento e microaspersão. Maringá: EDUEM, 2012. 356p.

Gupta, B.; Nayak, A. K.; Kandar, T. K.; Nair, S. Investigation of airwater two phase flow through a Venturi. Experimental Thermal and Fluid Science, v.70, p.148-154, 2016. https://doi.org/10.1016/j. expthermflusci.2015.07.012

Hoffman, G. J.; Evans, R. G.; Jensen, M. E.; Martin, D. L.; Elliott, R. L. Design and operation of farm irrigation systems. 2.ed. St. Joseph: American Society of Agricultural and Biological Engineers, 2007. $863 p$.
ISO - International Organization for Standardization. ISO 15873: Irrigation equipment - Differential pressure Venturi-type liquid additive injectors. Genebra: International Organization for Standardization, 2002. 12p.

Kuldeep, R.; Saharan, V. K. Computational study of different venturi and orifice type hydrodynamic cavitating devices. Journal of Hydrodynamics, v.28, p.293-305, 2016. https://doi.org/10.1016/ S1001-6058(16)60631-5

Kumar, M.; Rajput, T. B. S.; Patel, N. Effect of system pressure and solute concentration on fertilizer injection rate of a venturi for fertigation. Journal of Agricultural Engineering, v.49, p.9-13, 2012.

Lamm, F. R.; Ayars, J. E.; Nakayama, F. S. Microirrigation for crop production. Amsterdam: Elsevier, 2006. 642p.

Lemons, D. S. A student's guide to dimensional analysis. New York: Cambridge University Press, 2017. 112p.

Lima Neto, I. E.; Porto, R. M. Performance of low-cost ejectors. Journal of Irrigation and Drainage Engineering, v.130, p.122-128, 2004. https://doi.org/10.1061/(ASCE)07339437(2004)130:2(122)

Liu, K.; Lu, H.; Guo, X.; Sun, X.; Tao, S.; Gong, X. Experimental study on flow characteristics and pressure drop of gas-coal mixture through Venturi. Power Technology, v.268, p.401-411, 2014. https://doi.org/10.1016/j.powtec.2014.07.019

Manzano, J.; Palau, C. V.; Azevedo, B. M. de; Bomfim, G. V. do; Vasconcelos, D. V. Diseño y alternativas em la instalación de inyectores Venturi en riego localizado. Revista Ciência Agronômica, v.46, p.287-298, 2015.

Manzano, J.; Palau, C. V.; Azevedo, B. M. de; Bomfim, G. V.; Vasconcelos, D. V. Geometry and head loss in Venturi injectors though computational fluid dynamics. Engenharia Agrícola, v.36, p.482-491, 2016. https://doi.org/10.1590/1809-4430-Eng. Agric.v36n3p482-491/2016

Manzano, J.; Palau, C. V.; Azevedo, B. M. de; Bomfim, G. V. do; Vasconcelos, D. V. Characterization and selection method of Venturi injectors for pressurized irrigation. Revista Ciência Agronômica, v.49, p.201-210, 2018. https://doi. org/10.5935/1806-6690.20180023

Perboni, A.; Frizzone J. A.; Camargo, A. P. de; Pinto, M. F. Modelling head loss along emitting pipes using dimensional analysis. Engenharia Agrícola, v.35, p.442-457, 2015. https:// doi.org/10.1590/1809-4430-Eng.Agric.v35n3p442-457/2015

Provenzano, G. P.; Alagna, V.; Autovino, D.; Juarez, J. M.; Rallo, G. Analysis of geometrical relationships and friction losses in small-diameter lay-flat polyethylene pipes. Journal of Irrigation and Drainage Engineering, v.142, p.1-9, 2016. https://doi. org/10.1061/(ASCE)IR.1943-4774.0000958

Santos, L. da C.; Zocoler, J. L.; Justi, A. L.; Silva, A. O.; Correia, J. de S. Estudo comparativo da taxa de injeção em injetor do tipo Venturi com e sem válvula de retenção. Irriga, v.edição especial, p.145-154, 2012. https://doi.org/10.15809/irriga.2012v1n01p145

Silva, P. F. da; Lima, C. J. G. de S.; Barros, A. C.; Silva, E. M. da; Duarte, S. N. Sais fertilizantes e manejo da fertirrigação na produção de tomateiro cultivado em ambiente protegido. Revista Brasileira de Engenharia Agrícola e Ambiental, v.17, p.11731180, 2013. https://doi.org/10.1590/S1415-43662013001100007 
Sinha, I.; Buttar, G. S.; Brar, A. S. Drip irrigation and fertigation improve economics, water and energy productivity of spring sunflower (Helianthus annuus L.) in Indian Punjab. Agricultural Water Management, v.185, p.58-64, 2017. https://doi.org/10.1016/j. agwat.2017.02.008

Tian, D.; Zhang, Y.; Zhou, Y.; Mu, Y.; Liu, J.; Zhang, C.; Liu, P. Effect of nitrification inhibitors on mitigating $\mathrm{N}_{2} \mathrm{O}$ and $\mathrm{NO}$ emissions from an agricultural field under drip fertigation in the North China Plain. Science of the Total Environment, v.598, p.87-96, 2017. https://doi.org/10.1016/j.scitotenv.2017.03.220

Vekariya, P. B.; Subbaiah, R.; Mashru, H. H. Hydraulics of microtube emitters: A dimensional analysis approach. Irrigation Science, v.29, p.341-350, 2010. https://doi.org/10.1007/s00271-010-0240-6

Vilaça, F. N.; Camargo, A. P. de; Frizzone, J. A.; Mateos, L.; Koech, R. Minor losses in start connectors of microirrigation laterals. Irrigation Science, v.35, p.227-240, 2017. https://doi.org/10.1007/ s00271-017-0534-Z
Wu, W.; Chen, W. E. I.; Liu, H; Yin, S.; Niu, Y. A new model for head loss assessment of screen filters developed with dimensional analysis in drip irrigation systems. Irrigation and Drainage, v.63, p.523-531, 2014. https://doi.org/10.1002/ird.1846

Xu, Y.; Zhang, Q.; Zhang, T.; Ba, X. An overreading model for nonstandard Venturi meters based on $\mathrm{H}$ correction factor. Measurement, v.61, p.100-106, 2015. https://doi.org/10.1016/j. measurement.2014.10.028

Yuan, Z.; Choi, C. Y. Waller, P. M.; Colaizzi, P. Effects of liquid temperature and viscosity on venturi injectors. Transactions of the American Society Agricultural Engineers, v.43, p.1441-1447, 2000. https://doi.org/10.13031/2013.3042

Zitterell, D. B.; Frizzone, J. A.; Rettore Neto, O. Dimensional analysis approach to estimate local head losses in microirrigation connectors. Irrigation Science, v.32, p.169-179, 2013. https://doi. org/10.1007/s00271-013-0424-y 